\title{
Panorama das Comissões da Verdade no Brasil: uma reflexão sobre novos sentidos de legitimidade e representação democrática
}

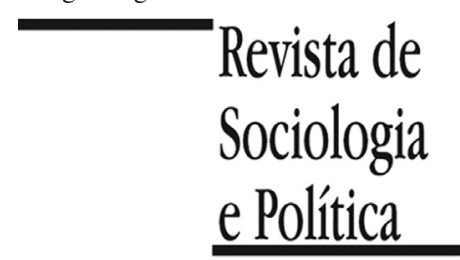

DOI 10.1590/1678-987319277006

\author{
Cristina Buarque de Hollanda'id e \\ Vinícius Pinheiro Israel ${ }^{I I, I I I}$ (iD \\ IDepartamento de Estudos Políticos, Instituto de Estudos Sociais e Políticos, UERJ, Rio de Janeiro, RJ, Brasil

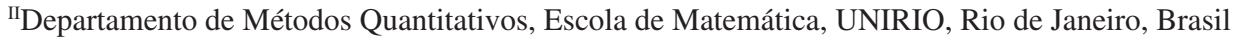 \\ IIIDepartamento de Estudos Sociais, Instituto de Estudos Sociais e Políticos, UERJ, Rio de Janeiro, RJ, Brasil
}

\begin{abstract}
RESUMO Introdução: A Comissão Nacional da Verdade (CNV) foi estabelecida no Brasil, em maio de 2012, com o objetivo de investigar os crimes da ditadura civil-militar (1964-1985) quase trinta anos depois da nova democracia no país. Ela foi sucedida pela proliferação de comissões subnacionais da verdade, organizadas por setores da sociedade civil, governos e legislativos municipais e estaduais. A difusão delas caracteriza-se como fenômeno singular no mundo, que denominaremos por comissionismo. Além de descrever o fenômeno, esse artigo se dedica a examinar e contrastar os diferentes repertórios de auto-justificação das comissões. Material e Métodos: A análise baseia-se em dados coletados sistematicamente pelos autores e sua equipe de pesquisa nos relatórios finais das comissões, em redes sociais, jornais nacionais e locais e entrevistas semi-estruturadas com comissionários. Resultados: Este artigo sustenta que, diferentemente de comissões da verdade no mundo e da própria CNV, o principal mecanismo difusor das comissões subnacionais da verdade no Brasil foi a normalização de vítimas como atores de representação legítima, habilitadas pela autoridade moral da experiência. Discussão: Na ausência de mecanismos de autorização e accountability das comissões da verdade, seus vários operadores acordaram e divergiram sobre seus fundamentos legítimos. Se, por um lado, eles concordam sobre o objetivo moral dos direitos humanos e sobre a expectativa de que o esclarecimento da "verdade" sobre violências passadas seja um meio de efetivá-los, por outro lado, existe substancial desacordo sobre os valores-motores das comissões. Estes podem ser descritos, com modulações, por analogia com as noções de imparcialidade ativa e proximidade, tal como articuladas por Pierre Rosanvalón, e também de perspectiva, tal como mobilizada por Iris Young.
\end{abstract}

PALAVRAS-CHAVE: comissões da verdade; democracia; direitos humanos; legitimidade; representação.

Recebido em 14 de Dezembro de 2017. Revisado em 7 de Fevereiro de 2019. Aceito em 2 de Julho de 2018.

\section{Introdução ${ }^{1}$}

\footnotetext{
${ }^{1}$ Este artigo consolida parte dos resultados de pesquisa financiada pela Fundação de Amparo à Pesquisa do Estado do Rio de Janeiro e pela Universidade do Estado do Rio de Janeiro (Prociência). Pudemos contar, em diferentes momentos, com a colaboração de Amanda Evelyn Lima, Ana Carolina Santos, Aparecido Silva, Arnaldo Lucas Pires Junior, Caroline Caldas, Joyce Abbade, Lucas Burgos, Mayara Gonçalves, Natalia Costa, Rafael Massena, Raul Ribeiro e Silvana Teles. Somos também gratos a Mariana Possas e Alexandre
}

$\mathrm{N}$ o Brasil contemporâneo, o tópico da crise de representação se tornou lugar comum do discurso político. Seus vários locutores divergem na imaginação de remédios e futuros para a política, mas convergem no diagnóstico de que os sentidos de legitimidade da democracia ultrapassam suas dimensões eleitoral e partidária. Embora a retórica da crise se ancore em sentidos de novidade e urgência, ela anima os debates acadêmico e político no país desde o retorno ao sistema democrático, em 1985.

Ao lado do lamento estéril e das expressões de repúdio às instituições, o ceticismo sobre as formas da política também teve ecos criativos: nas últimas décadas, o país conheceu espaços de interação entre sociedade e Estado inovadores, que prescindem da mediação eleitoral (AVRITZER 2007; AVRITZER 2008; LAVALLE 2006a; LAVALLE 2006b; LAVALLE \& VERA 2011); MIGUEL 2005). O marco desta inflexão foi a Constituição de 1988 e, na sequência dela, os novos arranjos legislativos em esferas estadual e municipal. Eles permitiram - em vários níveis e modalidades - a aproximação entre atores 
Werneck pela participação nas discussões iniciais da pesquisa e, por fim, à leitura atenta dos pareceristas anônimos da Revista de Sociologia e Política, que nos sugeriram importantes modificações.

\footnotetext{
2 As comissões da verdade são corpos sem caráter jurídico que se difundiram a partir dos anos 1980 para investigar violações de direitos humanos cometidas por governos autoritários ou grupos agressores em países recém-egressos de regimes autoritários e guerras civis. $\mathrm{O}$ Transitional Justice Research Collaborative, da Universidade de Harvard, criou metodologia que pretende avaliar seu desempenho.

${ }^{3}$ A estimativa é do relatório final da CNV, publicado em dezembro de 2014 e a referência é ao conjunto de comissões da verdade com e sem vínculos com o Estado. Isto é, sediadas em estados, municípios e também em universidades, sindicatos e associações profissionais. A contagem precisa das comissões da verdade no país é um desafio para o pesquisador.

${ }^{4}$ A Comissão da Verdade e da Preservação da Memória do Estado da Paraíba, por exemplo, enfatizou as investigações sobre violências cometidas contra camponeses (ver HOLLANDA 2019e) e a Comissão da Verdade do Amapá atentou para o "viés econômico" da ditadura e seus efeitos "anti-civilizatórios", que atingiu sobretudo as "populações tradicionais" do estado (ver HOLLANDA 2019c, p.10).
}

civis e sistema político nos processos de criação, execução e controle de políticas públicas. As experiências brasileiras se somaram ao repertório do que Pierre Rosanvallón nomeou "fóruns híbridos", disseminados pelo mundo nos anos 1990 como materialização de novas figuras de legitimidade democrática (ROSANVALLÓN 2009, p.295). Nos anos 2000, durante os governos Luiz Inácio Lula da Silva (2003-2011), esses lugares de interação se fizeram mais numerosos, diversos e vigorosos e foram descritos, com entusiasmo, como exemplos de "experimentalismo democrático" (POGREBINSCHI \& SANTOS 2011). Em meio à coleção extensa de comitês e colegiados, consultivos, deliberativos ou fiscalizadores, com diferentes composições, escopos e articulações com setores da administração pública, três deles tenderam a concentrar a atenção de estudiosos: os Conselhos Gestores de Políticas Públicas, as experiências de Orçamento Participativo e as conferências nacionais (entre outros, ver: AVRITZER 2007; AVRITZER 2008; LAVALLE 2006a; LAVALLE 2006b; LÜCHMANN 2011).

Mais recentemente, outro dispositivo de interlocução entre Estado e grupos organizados da sociedade ganhou força na cena pública brasileira: as comissões da verdade para apurar crimes da ditadura militar. Elas existiram em muitos outros países no mundo e chegam a constituir uma espécie de fórmula política para países recém-egressos de regimes violadores de direitos humanos ${ }^{2}$. A partir da criação da Comissão Nacional da Verdade (CNV), em novembro de 2011, elas proliferaram por todo Brasil e, três anos depois, já contavam cerca de uma centena, com formas variadas, vinculadas ou não a instâncias de Estado ${ }^{3}$. Independentes entre si, estiveram desobrigadas da produção de uma única e coerente narrativa nacional sobre a ditadura ${ }^{4}$.

Não sendo autorizadas pelo voto, comissões da verdade costumam mobilizar - no Brasil e fora dele - uma noção de democracia amalgamada aos direitos humanos. A partir dela produzem justificação ou legitimação pública de suas atividades. Comissões da verdade constituem um objeto amplamente abordado a partir da literatura de justiça de transição ${ }^{5}$, mas ainda inexplorado pelo prisma da representação política. Embora membros de comissões da verdade - que passaremos a nomear comissionários - não tenham por hábito reivindicar expressamente a identidade de representantes das vítimas - e, neste sentido, não constituam objeto para um debate sobre representação em moldes tradicionais -, eles evocam a representação (ou o "falar em nome") de causas, valores, bandeiras e direitos de pessoas afetadas pela ditadura, ou mesmo da população em geral, quando articulam a defesa genérica de direitos. Aproximam-se, deste modo, das experiências que informaram a inflexão recente na literatura sobre representação, calcada na investigação de figuras não-eleitorais de legitimidade da ação política (a exemplo de ROSANVALLÓN 2009 e SAWARD 2010).

Neste artigo, interpretaremos nossa pesquisa empírica à luz, portanto, de categorias da literatura sobre representação política - isto é, as noções de imparcialidade ativa, de um lado, e proximidade (ROSANVALLON 2009) e perspectiva (YOUNG 2001), de outro. Nosso corpus documental se concentra sobre comissões da verdade com vínculos estatais e se organiza em dois eixos. O primeiro deles é constituído por onze entrevistas em profundidade conduzidas ao longo dos anos de 2014 e 2015 com dez comissionários em todo país. ${ }^{6}$ O segundo eixo reúne informações extraídas dos relatórios finais e consultas a membros de 45 comissões estaduais e municipais da verdade (ver apêndice 1) sobre sua filiação institucional, data de instalação, recomendações, redes de colaboração e perfil de comissionados. ${ }^{7}$

A primeira seção do artigo tem o objetivo de descrever o processo de multiplicação das comissões da verdade no Brasil, a que chamaremos sucintamente de comissionismo ${ }^{8}$. Faremos isso em comparação com aspectos gerais da 
${ }^{5}$ A partir dos anos 1980, a afirmação da justiça de transição como novo campo do saber foi animada por um forte sentido de urgência, motivado pelo objetivo de lidar com dilemas de democracias jovens e frágeis. Neste artigo, a investigação sobre comissões da verdade tem um propósito eminentemente analítico, desobrigado das "lições úteis" comentadas por Neil Kritz (KRITZ 2004, p.XIX). experiência de comissões da verdade no mundo, observando afinidades e dissonâncias. Neste esforço, caracterizaremos a condição descentralizada e heterogênea do fenômeno brasileiro, com atenção para sua diversa composição institucional e partidária, sua distribuição temporal, seus vetores de colaboração e conjuntos de recomendações. Na segunda seção, observaremos os repertórios comuns de justificação pública articulado por atores do comissionismo. Em seguida, na última seção, deslocaremos a atenção para os desacordos entre comissões da verdade, referidos a diferentes visões sobre em que consiste - ou deve consistir - a legitimidade da sua figura pública ou a sua capacidade de representação de causas. A tensão entre os princípios já referidos de imparcialidade ativa, de um lado, e proximidade e perspectiva, de outro, é sobretudo explicitada, como se verá, no conflito de perspectivas entre a CNV e a Comissão da Assembleia Legislativa do Estado de São Paulo Rubens Paiva (CEVAL-SP). No quadro mais amplo do comissionismo, o contraponto duro entre CNV e a Comissão Rubens Paiva (CRP) ganha nuances e sobreposições. Os direitos humanos são traduzidos em ativismo aproximado a parâmetros internacionais e também em práticas francamente dissonantes deles, em redes de cooperação e conflito. Sobre estas grandes questões debruça-se este artigo.

\section{Comissões da verdade no mundo e no Brasil}

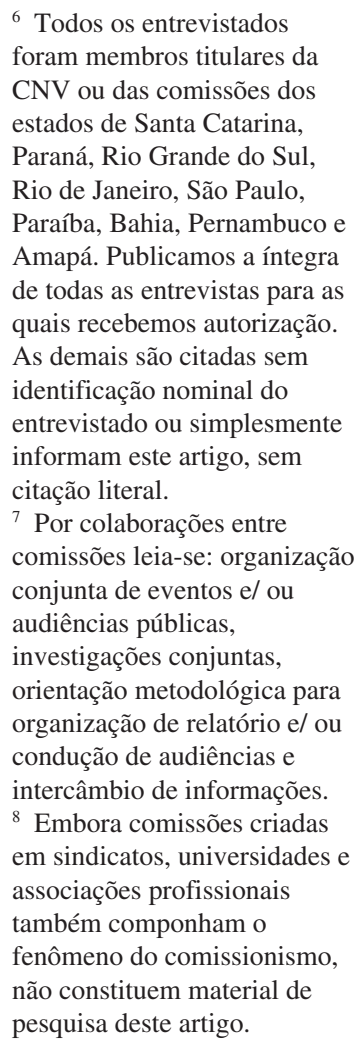

Comissões da verdade se espalharam pelo mundo a partir dos anos 1980 e 1990, acompanhando o que Huntigton chamou de "terceira onda de democratização" (HUNTINGTON 1994). Em países de transição política recente, com frágeis e incertos arranjos de poder, elas se apresentaram como alternativa ao modelo disruptivo de tribunais judiciais. Sem poderes de arbitrar penas, a suposição comum é que comissões da verdade permitam abordar o problema das violações de direitos humanos sob regimes autoritários (ou durante períodos de guerra) com baixos níveis de tensionamento da ordem instituída. A partir do caso sul-africano e sua paradigmática Comissão de Verdade e Reconciliação, as comissões movimentaram comunidades de defensores - afeitos ao princípio da reconciliação social como condição de futuro para a política (a exemplo de TUTU 1999; BORAINE 2008; HAYNER 2011) - e críticos - que demandam o princípio de reciprocidade penal encarnado em tribunais domésticos e internacionais (como WILSON 2001). Há também aqueles que enxergam as comissões como um primeiro passo em direção a encaminhamentos judiciais futuros e as saúdam como instrumento primeiro ou preliminar na abordagem do problema das violações passadas de direitos humanos (SIKKINK 1995).

Foram diversas as metodologias e também os escopos de ação desses novos fóruns, variáveis, em grande medida, com contextos locais de transição política. A despeito disso, um conjunto mínimo de convergências caracterizou e caracteriza sua performance no mundo. Grosso modo, comissões da verdade foram ou são (i) corpos não jurídicos (ii) organizados nacionalmente (iii) durante períodos de transição política (iv) em torno dos princípios de escuta e autoridade moral de pessoas auto identificadas e reconhecidas vítimas cujos (v) testemunhos são recolhidos por figuras idealmente reputadas por sua moderação e capacidade de escuta e mediação de atores em lados opostos de sociedades divididas. Essas figuras, (vi) os comissionários, distinguem-se essencialmente das vítimas, pois, diferentemente delas, não foram objeto direto da violência de Estado ou dos grupos guerreiros. (vii) Sua não-afetação garante, em princípio, o lugar de independência que é condição da imparcialidade e da credibilidade para produzir uma narrativa coerente e abrangente sobre o período violento que deverá ser apresentada ao público em forma de relatório e em compromisso com os valores de direitos humanos. (viii) Nesse documento final, os inúmeros casos de vitimação individual são articulados em torno de uma narrativa que se pretende abrangente e consensual mesmo em contextos de profunda divisão so- 
${ }^{9}$ A esse respeito, Paulo Abrão e Marcelo Torelly observam que o país seguiu um caminho transicional organizado, a partir dos anos 1990, em torno do princípio da reparação, já previsto na Lei de Anistia de 1979. Antes das comissões da verdade, ele orientou os trabalhos da Comissão de Mortos e Desaparecidos Políticos (1995) e da Comissão de Anistia (2003) (ABRÃO \& TORELLY 2011; SIMONI 2016).

${ }^{10}$ Para um mapeamento possivelmente exaustivo de comissões da verdade no mundo, ver Stan, 2014.

\author{
11 A diversidade dos \\ instrumentos de criação das \\ comissões delimitaram \\ diferentes escopos de ação e \\ níveis de autonomia. \\ Comissões criadas por leis e \\ vinculadas a governos \\ estaduais ou municipais \\ tenderam a ser mais robustas e \\ menos suscetíveis a oscilações \\ da política, pois não se \\ extinguiam com o fim dos \\ mandatos.
}

cial. Como consequência, (xix) busca-se garantir a não-repetição do passado e seus ciclos de violência.

Esse quadro geral tem importantes pontos de aproximação e distinção em relação à experiência das comissões da verdade no Brasil. A CNV e outras comissões estaduais que emulam o seu modelo respondem pelo polo das aproximações. Elas satisfazem largamente o modelo exposto, embora destoem dele na temporalidade tardia em relação à transição para a democracia: cerca de trinta anos se passaram entre o fechamento formal da ditadura e a sua criação ${ }^{9}$.

Quanto ao polo de distinções, além da decalagem temporal, o Brasil diverge de situações arquetípicas de comissões da verdade no mundo pela condição radicalmente plural da experiência do comissionismo. Diferentemente da organização sempre e apenas nacional das comissões da verdade no mundo, com eventuais sedes regionais vinculadas a escritórios centrais ${ }^{10}$, o Brasil conheceu um fenômeno sui generis de proliferação de comissões da verdade em municípios, estados e instâncias extra-estatais. Ele se deu por efeito contágio, sem articulação de um agente central, aglutinador e propulsor. O comissionismo ultrapassou a iniciativa política de seu único fórum nacional e se expandiu em torno de dinâmicas locais de mimesis institucional, com múltiplos centros e mecanismos difusores pelo país. Embora a CNV tenha ocupado posição pioneira e de protagonismo durante parte significativa deste processo, com algum empenho na indução de estruturas similares nos estados, não chegou a assumir esse papel de maneira robusta ou a exercer função diretiva. A condição heterogênea do comissionismo será abordada nesta seção a partir de quatro variáveis (institucional, temporal, partidária e de redes), com foco nas comissões com algum tipo de vínculo estatal.

Os vários desenhos institucionais das comissões - a que corresponderam diferentes mandatos, disponibilidade orçamentária, raios e repertórios de ação estiveram contidos no âmbito do executivo federal e de legislativos e executivos estaduais e municipais. Excetuando-se a $\mathrm{CNV}$, que foi a única comissão da verdade criada por lei federal e vinculada à presidência da República, 28 delas foram criadas por leis ou decretos estaduais ou municipais e estiveram relacionadas a executivos estaduais e municipais (sendo 14 estaduais e 14 municipais) e 17 foram comissões legislativas vinculadas a assembleias estaduais e câmaras municipais (sendo 14 destas municipais, concentradas sobretudo nos estados de São Paulo e do Rio de Janeiro e apenas 4 estaduais), conforme Figura 1. ${ }^{11}$

A CNV foi uma espécie de marco zero do comissionismo. Depois dela, uma onda de comissões semelhantes, com menores e variados escopos, orçamentos e poderes, tomou conta das principais capitais do país e também de municípios localizados sobretudo nos estados do Rio de Janeiro e de São Paulo. A possibilidade de a CNV colaborar com "órgãos e entidades, públicos ou privados, nacionais ou internacionais" [lei 12.528, de 18 de novembro de 2011] propiciou a assinatura de uma série de protocolos de colaboração com comissões de filiações diversas, estatais ou não - mas isso não significou uma relação de causalidade estrita entre a CNV e o comissionismo, como já se observou. Nos âmbitos estatais, parte significativa das comissões da verdade foi constituída a partir de ou em colaboração com comitês por memória, verdade e justiça, ligados a setores organizados da sociedade.

Os comitês se multiplicaram pelo país em torno da bandeira de defesa do Plano Nacional de Direitos Humanos 3 (PNDH3) ${ }^{12}$, cujo decreto original, assinado pelo presidente Luiz Inácio Lula da Silva em dezembro de 2009, foi objeto de reação contundente capitaneada por setores militares. Segundo Manoel Severino Moraes - que veio a ser membro titular da Comissão Dom Helder Camara, de Pernambuco, mas que foi antes membro do comitê pernambucano -, temia-se, à época, a possibilidade de não efetivação do Plano - e, por conse-
12 O PNDH3 foi constituído após ampla consulta a segmentos organizados da sociedade civil, em todo país, na forma de conferências locais, regionais e nacional 
(11 ${ }^{\text {a }}$ Conferência Nacional de Direitos Humanos).

13 O protagonismo de Gilnei Vianna na articulação original de comitês de memória, verdade e justiça é uma espécie de conhecimento comum entre ativistas da causa. Além da evocação muito explícita por Manoel Moraes, na entrevista aqui referida, o nome de Gilnei surgiu em conversas informais, palestras e entrevistas, sempre em associação aos comitês.

${ }^{14}$ Embora muitíssimo relevantes na história
Figura 1 - Comissões subnacionais por estado e município

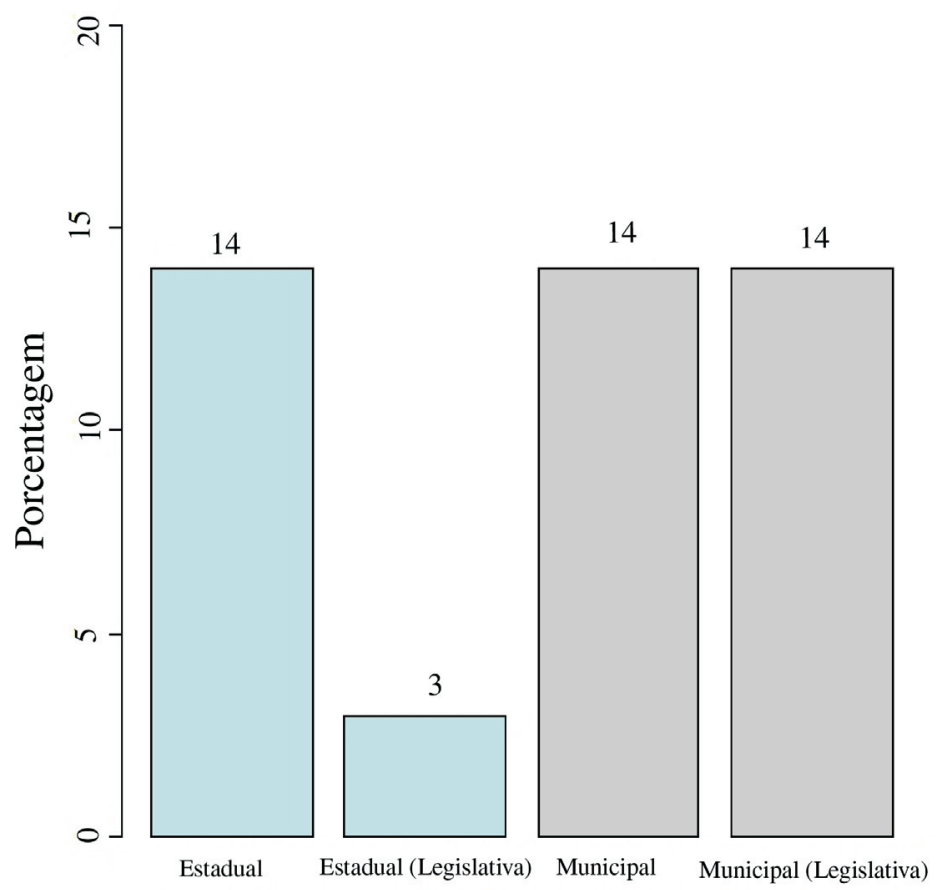

Fonte: Elaboração própria.

quência, a desarticulação da comissão da verdade prevista nele, que ainda não tinha o nome nem a forma da Comissão Nacional da Verdade (HOLLANDA 2019b, p.47). Em maio de 2010, novo decreto do PNDH3 trouxe acomodações com os segmentos insatisfeitos, mas não retirou a comissão da verdade, em âmbito nacional, do horizonte político.

Foi naquele hiato de incerteza - e também antes e depois dele - que os setores alinhados com a demanda por esclarecimento sobre as ações da ditadura, em variados lugares institucionais, se mobilizaram fortemente. A partir do Ministério da Justiça - e especificamente a partir de uma de suas diretorias específicas, de memória e verdade, então conduzida por Gilnei Viana - produziu-se incentivo informal para a articulação local de comitês da sociedade dedicados à pauta de "memória, verdade e justiça"13. Moraes e Viana dividiam o "sentimento" de que era preciso "fazer um movimento social específico em torno dessa questão de justiça de transição" (HOLLANDA 2019c, p.47). Eles idealizavam comitês dedicados à supervisão dos trabalhos da CNV e também ao fomento e à articulação em nível estadual de comissões dedicadas a investigar a ação local da ditadura. Nesse processo, houve, na expressão de Desirée de Azevedo, seguidos atravessamentos das fronteiras entre Estado e sociedade (AZEVEDO 2018). A despeito de importantes e diversas tensões, que variaram ao sabor de histórias e poderes locais, atores sociais e estatais operaram em estreita cooperação. No lugar de uma dualidade estrita entre esses dois domínios, a experiência do comissionismo revela, em alinhamento com as premissas do neo-institucionalismo histórico (SKOCPOL 1992; LAVALLE et all 2019 e outros), relações de mútua determinação entre sociedade e Estado.

O comissionismo contou, portanto, com o lastro significativo da ação de familiares, ex-perseguidos políticos e ativistas atraídos pelas pautas de "memória, verdade e justiça" ${ }^{4}$, situados dentro e fora do Estado. Além dos instrumentos verticais de indução da mobilização (a exemplo da CNV e do próprio 
transicional do Brasil, as ações de familiares de mortos e desaparecidos pela ditadura e também de ex-perseguidos e demais ativistas do

"movimento por memória, verdade e justiça" escapam ao recorte deste artigo. Elas são em parte reconstituídas em AZEVEDO 2018 e SIMONI 2016.

15 Nesse artigo, usamos um entendimento restrito das noções de afetação e afetados. Isto é, referimo-nos estritamente a pessoas que sejam familiares de mortos ou desaparecidos pela ditadura ou que tenham sido elas próprias perseguidas pela ditadura - isto é, constrangidas ao exílio, demitidas ou que tenham tido matrículas ou mandatos cassados.
Gilnei Viana, na qualidade de operador do Ministério da Justiça), que marcam sobretudo a primeira fase do fenômeno, o efeito-contágio de algumas comissões sobre outras deu o tom do cenário expansivo. Em 13 de outubro de 2013, o Diário do $\mathrm{ABC}$ anunciou: Comissão da verdade vira moda no Grande ABC. Em todo o país, a moda articulou grupos já historicamente mobilizados pela denúncia da violência da ditadura com novas gerações que não têm histórias de afetação direta ${ }^{15}$ pelo regime, mas que se solidarizam com a causa.

A Figura 2 apresenta o mapa temporal do comissionismo. Ela captura o período de explosão das comissões de verdade no Brasil.

Como se pode observar, das 44 comissões estaduais e municipais da verdade em curso durante o mandato da CNV, apenas 11 encerraram seus trabalhos junto com ela. Outras tantas, em articulação com o calendário de extinção da $\mathrm{CNV}$, produziram relatórios parciais que, somados aos relatórios finais das comissões concluintes, produziram insumo para o relatório final da CNV. Se a importância da CNV na articulação da cena nacional do comissionismo não foi secundária, tampouco ela figurou como instrumento de orquestração do fenômeno. As 33 comissões cujos mandatos continuaram vigentes seguiram seu curso à própria sorte - em voos solo ou engajadas em redes locais de colaboração (como se verá na Figura 3). No caso da Comissão Estadual de Sergipe, não teve nenhum período de superposição temporal com a $\mathrm{CNV}$, tendo iniciado suas atividades quase um ano depois de encerrado o mandato da nacional.

As dinâmicas de efeito-contágio, como já referimos, ou de mimesis institucional se propagam por vetores verticais e horizontais. Verticalmente, existe um fluxo de inspiração $0^{16}$ (ou rejeição ${ }^{17}$ ) que opera de cima para baixo - num movi-

${ }^{16}$ Caso da Comissão da

Figura 2 - Tempo de duração das comissões da verdade (até janeiro de 2017)

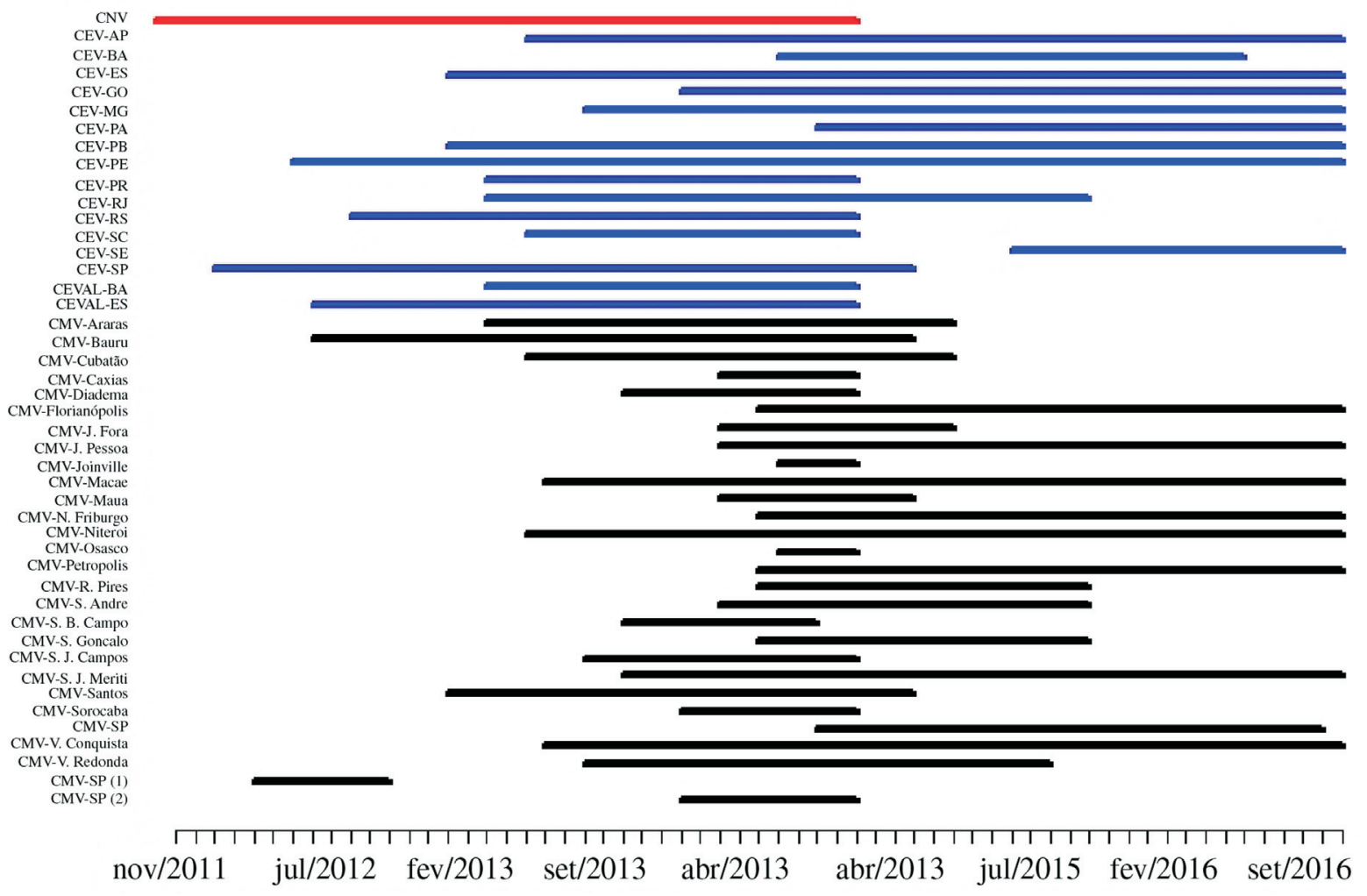

Fonte: Elaboração própria.

Observação: Os inícios das barras horizontais referem-se aos períodos de instalação e o final aos períodos de extinção das comissões. 
Figura 3 - Grafo das contribuições e auxílios entre as comissões de verdade

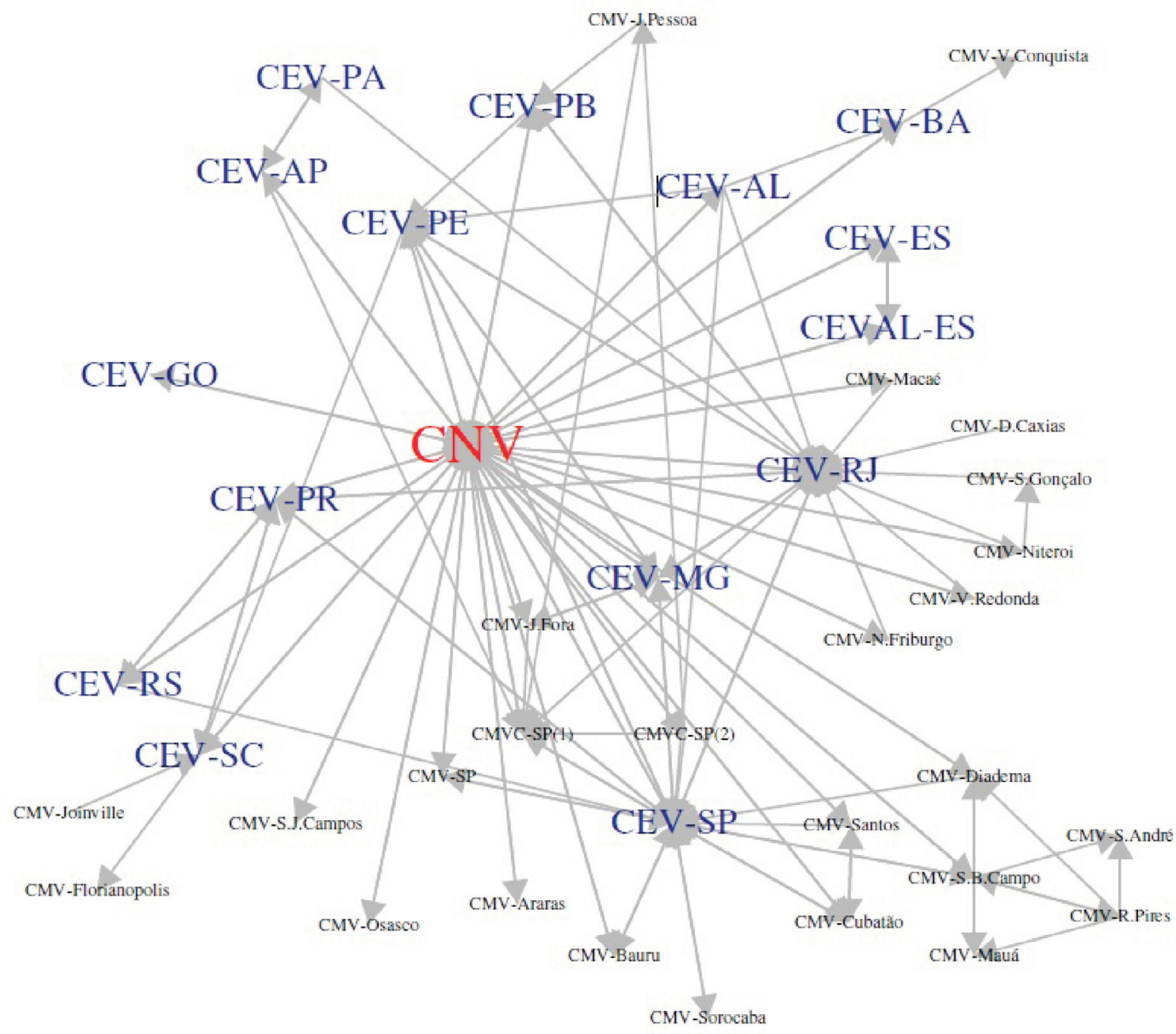

Fonte: elaboração própria a partir dos relatórios finais das comissões da verdade e de consulta a comissionários ou funcionários de comissões.

Verdade do Rio Grande do Sul (CEV-RS), que aderiu fortemente aos parâmetros da CNV.

${ }_{17}$ A noção de rejeição é chave para o argumento na segunda seção do artigo, que trata do comportamento antagônico da CRP em relação à CNV. A primeira, como será visto, define sua identidade em torno da negativa dos princípios de legitimação institucional da CNV, embora dessa tensão explícita não resulte ausência de cooperação.

${ }^{18}$ Num ambiente

caracterizado pela internacionalização do discurso sobre direitos humanos e seus mecanismos, o eixo vertical pode, mento que vai dos padrões internacionais em direção ao domínio nacional, encarnado na CNV, e, então, dela em direção aos níveis estadual e municipal ${ }^{18}$. Horizontalmente, pode-se observar um fluxo significativo de inspiração de um estado ou município para outro ${ }^{19}$. Isso se deve ao fato de comissões da verdade de estados e municípios vizinhos potencialmente dividirem percepções e objetivos que as distinguem das realidades locais específicas de outras comissões e que as permitem produzir narrativas aproximadas sobre "a verdade". ${ }^{20}$

Como resultado da interação dessas variáveis, o comissionismo pode ser descrito como um emaranhado amplo e frágil de redes institucionais. Entre as comissões subnacionais, mesmo as menores e com menos recursos, mostraram forte tendência a agir de modo independente, associando-se livre e diretamente a comissões parceiras. Na coleta de dados para esta pesquisa, foram obtidas informações sobre as redes de auxílio e cooperação entre as comissões. A Figura 3 sintetiza o argumento da dispersão que vimos mobilizando para caracterizar o comissionismo e mostra como as várias comissões (CNV, estaduais e municipais) mantiveram contatos de ajuda mútua, com variados vetores. 
frequentemente, articular os domínios internacional e local, prescindindo de mediação da CNV. Foi o caso da Comissão da Verdade de Pernambuco (CEV-PE), inspirada por protocolos internacionais de justiça transnacional e também por experiências internacionais exemplares.

19 É o caso da já mencionada "moda" de comissões da verdade no Grande ABC, região que envolve a região metropolitana da cidade de São Paulo compreendendo as cidades de Santo André (A), São Bernardo do Campo (B), São Caetano do Sul (C), incorporando ainda, Diadema, Mauá e Ribeirão Pires.

${ }^{20}$ Ainda a título de exemplo recorremos às comissões do $\mathrm{ABC}$, que investigavam o envolvimento de empresas com o regime militar, tendo coletado informações sobre a rede de conexões entre as "listas sujas" e outras práticas de perseguição política operadas pelo mercado industrial local.
Os tracejados do grafo indicam vínculos de colaboração entre comissões, como orientação metodológica (para condução de oitivas, coleta e arquivamento de documentos e organização de relatório), investigações conjuntas ou sessões de testemunho organizadas em parceria. Pode-se perceber a centralidade da CNV e dois nós claros ao redor da CEV-RJ e da CRP. Outro fator relevante presente na Figura 4 é a contribuição mútua das comissões do Grande ABC paulista, que constituíram um núcleo colaborativo à parte. As setas no grafo indicam a direção que a contribuição foi dada, sem passar por mediação da CRP nem tampouco da CNV.

Por fim, ainda no esforço de descrição do comissionismo como cena heterogênea, abordamos seus vínculos político-partidários de origem. Apesar do inequívoco protagonismo político do Partido dos Trabalhadores - sobretudo nas comissões legislativas municipais concentradas na região do $\mathrm{ABC}$ paulista -, também a iniciativa política do fenômeno foi diversificada, conforme a Figura 4.

Embora o PT claramente predomine como iniciador de comissões da verdade, quase metade delas resultou da iniciativa política de vários partidos, incluindo PSDB e PMDB. Além disso, diversas comissões tiveram entre seus proponentes membros de partidos políticos pequenos ou proponentes não ligados a partidos, como mostra a barra Outros da Figura 4.

Embora guarde linhas muito evidentes de aproximação com características gerais do fenômeno das comissões da verdade no mundo, o comissionismo no Brasil em muitos aspectos se distingue marcadamente dele. Nesta seção, caracterizamos uma das dimensões dessa dissonância: a condição plural e radicalmente dispersiva das comissões da verdade, experimentadas como corpos autônomos na definição de calendários, métodos e "verdades" sobre a ditadura, articulados em redes que obedeceram menos a diretrizes centrais do que a identidades e entendimentos locais sobre a violência da ditadura. Passaremos agora a caracterizar a afinidade que sobrevive à dispersão das comissões: uma espécie de intersubjetividade compartilhada por comissionários (brasileiros e internacionais), alinhada em torno dos valores dos direitos humanos e da democracia.

Figura 4 - Distribuição das iniciativas de comissão por partido político

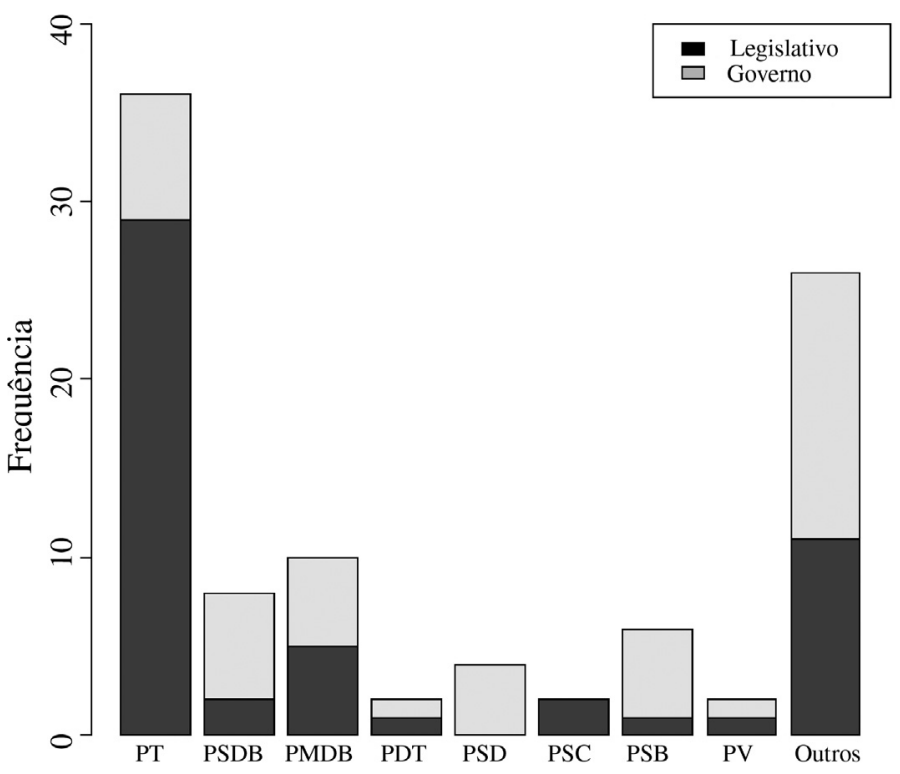

Fonte: Elaboração própria. 


\section{Comissionismo: o que une em meio à dispersão?}

A condição heterogênea, fragmentária e de baixa articulação institucional do comissionismo não configura uma cena amorfa, esvaziada de princípios comuns de vertebração. Esta seção do artigo se dedica justamente a apresentar três eixos comuns de justificação pública do fenômeno, fortemente imbricados entre si, apoiados em repertórios de legitimidade dos direitos humanos e elucidativos das suas afinidades com a cena de comissões da verdade no mundo. Uma vez que elas não resultam de autorização direta das populações com que reivindicam laços de identidade e representação, a validade destes vínculos é reivindicada em vista dos propósitos a que servem, tidos e ativamente afirmados como inquestionáveis. São eles: 1 . a pedagogia política da "verdade" isto é, a suposição de que a revelação dos malfeitos passados funda as condições para sua não-repetição; 2. a premissa de causalidade entre o desconhecimento sobre violações passadas de direitos humanos e o cometimento de violações presentes e, por fim; 3. as amarras necessárias entre democracia e direitos humanos - e, por derivação, o mau juízo sobre a experiência política em curso no Brasil.

Com respeito à pedagogia da "verdade", ela compreende um ritual declarativo ou, simplesmente, um ato de revelação de rotinas ou eventos de violência que antes não eram conhecidos além do círculo das pessoas que foram a eles expostos. Estabelecida a "verdade", supõe-se que estejam dadas as condições para superar a repetição de vícios passados. Entre comissionários tornou-se uma espécie de lugar comum a premissa de homologia entre saber e evitação do mal - ou, em linguagem nativa amplamente mobilizada nos relatórios das comissões, entre "verdade" e "nunca mais". Conforme expressão corrente entre comissionários: é preciso olhar o passado "para que se conheça, para que nunca mais aconteça". Trata-se, contudo, de tarefa árdua quando se supõe que a sociedade agoniza em uma cultura política "autoritária", "antirrepublicana" e "precária", segundo referiram, em entrevista para este projeto, comissionários do Amapá, de São Paulo e Minas Gerais, respectivamente.

Embora os mandatos de comissão tenham se concentrado sobre a investigação de crimes da ditadura, a alusão reiterada à violência policial em curso no país compôs o esforço de justificação pública das comissões, o que nos conduz ao segundo tópico da afinidade entre elas. Elas tenderam a fazer desta identificação entre violações passada e presente um elemento-chave de sua face pública. Um dos comissionários entrevistados, por exemplo, se espanta com o fato de "as pessoas" não associarem "a polícia que mata dentro de uma unidade da UPP [Unidade de Polícia Pacificadora] com uma polícia que matava dentro de um DOI/CODI [Departamento de Operações de Informação - Centro de Operações de Defesa Interna]"21. Comissionários amalgamaram passado e presente em alusões indistintas à violência de Estado e produziram um discurso angustiado pela necessidade de ruptura nunca conflagrada. "De quantos Amarildos $^{22}$ precisaremos para mudar as coisas?", pergunta o mesmo comissionário ${ }^{23}$.

Apesar de transcorridos quase 30 anos sob a nova Constituição, comissionários insistiram no uso da categoria "justiça de transição" para se referir à experiência das comissões porque identificavam uma incompletude fundamental da experiência democrática: as violações cotidianas de direitos humanos que vitimam sobretudo os pobres. Na sua perspectiva, se a democracia colide com os direitos humanos, é porque não se estabeleceu plenamente ou não foi suficientemente instruída. Faltou-lhe "verdade". Na simbiose suposta - ou ambicionada - entre democracia e direitos humanos, temos o terceiro eixo de afinidade entre comissões, explícito no conjunto de recomendações dos relatórios finais das comissões da verdade (ver Figura 5). Grosso modo, as recomen- 
militares na sede da UPP no bairro da Rocinha, no Rio de Janeiro, em 14 de julho de 2013. Este caso se tornou símbolo do abuso de autoridade e da violência policial.

${ }^{23}$ Dadas as condições políticas do país na altura da publicação deste artigo, o comissionário em questão solicitou preservação de sua identidade.

\footnotetext{
${ }^{24} \mathrm{O}$ entendimento de diversos comissionários é de que a restrição à investigação dos criminosos da ditadura se trata de um equívoco interpretativo, uma vez que graves violações de direitos humanos configuram crime imprescritível, conforme tratados internacionais dos quais o Brasil é signatário. Para uma abordagem sistemática do tema, em geral aproximada ao entendimento de comissionários, ver Abrão \& Torelly 2011.
}

Figura 5 - Relação simplificada das recomendações dos resultados das comissões

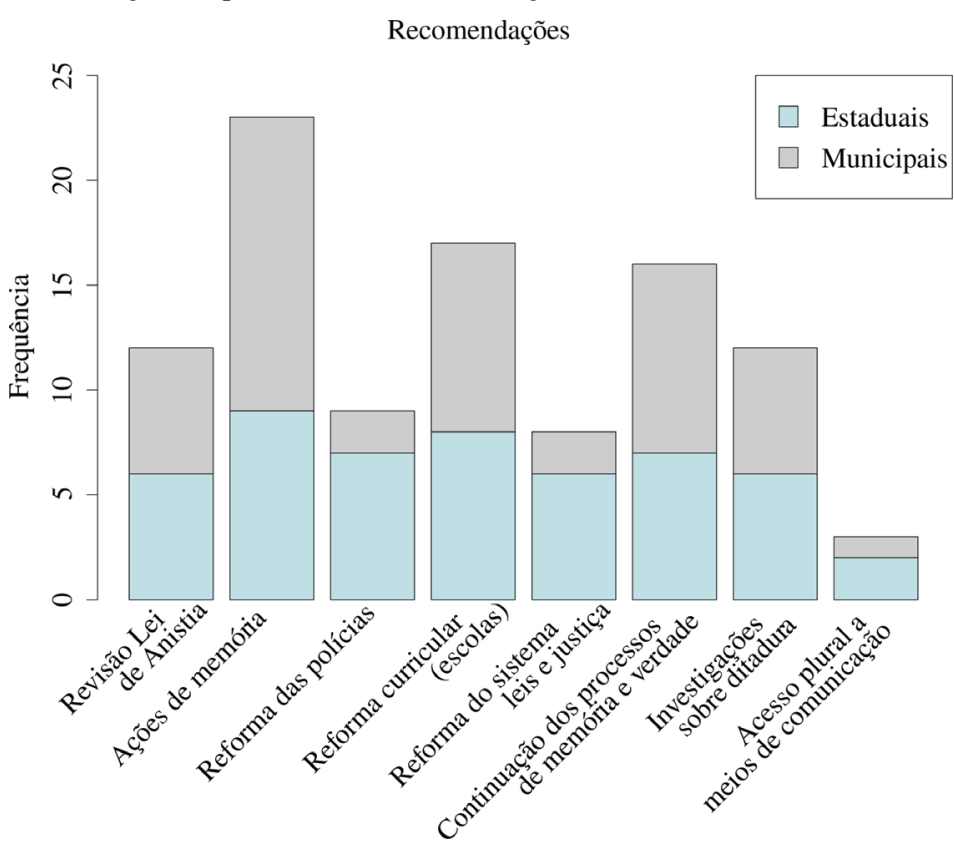

Fonte: Elaboração própria.

dações se dividem entre ações de memória em relação aos crimes da ditadura (tais como a alteração de nome de logradouros públicos, a construção de memoriais de resistência, a apresentação de pedidos oficiais de desculpas, entre outros) e a criação institucional de meios "para que não se repitam" (tal como ações de justiça social e de continuação das investigações sobre crimes da ditadura, além de reformas das polícias, dos currículos escolares, dos sistemas de leis e justiça e dos meios de comunicação).

Chama atenção entre as recomendações a demanda por revisão da Lei de Anistia ou da sua interpretação corrente ${ }^{24}$ - sobretudo nos relatórios de comissões estaduais (que exibem maior articulação com a questão nacional) do que as comissões municipais, marcadamente localistas. A adesão ao princípio de justiça restaurativa - típico de comissões da verdade e manifesto, por exemplo, na recomendação por políticas de memória - conviveu, no comissionismo, com a demanda por punição, calcada num sentido retributivo estrito. Na posição pública assumida por comissionários, o entendimento sobre a conjugação entre democracia e direitos humanos - que deverá produzir as condições para a não repetição do passado violento - oscila entre a busca por "verdade" e a punição de criminosos. Isto é, ora a "verdade" é evocada como fim em si mesmo - ela própria capaz de produzir as reparações necessárias e fazer a democracia encontrar os direitos humanos -, ora é concebida como meio ou instrumento para a punição, que encarnaria, efetivamente, a função pedagógica da comissão.

Tomados em conjunto, os três eixos analíticos e também normativos - isto é, a pedagogia da verdade, a premissa do nexo causal entre a violência do passado e do presente e o laço necessário entre democracia e direitos humanos - dão substrato à demanda representativa das comissões: eles abarcam, a um só tempo, o compromisso moral das comissões com as vítimas passadas e presentes do Estado violento. A premissa de razoabilidade das causas de direitos humanos (e dos meios para alcançá-los) assegura a validade da representação. Trata-se de uma espécie de "chão comum" entre operadores do comissionismo - que os filiam aos padrões correntes entre comissões da verdade no mundo. Essa dimensão de acordo não inibe, contudo, importantes dissonâncias, que 
complementam a primeira seção deste artigo na caracterização da distinção do comissionismo em relação ao fenômeno mais amplo das comissões da verdade no mundo. Elas, as dissonâncias, são objeto da próxima seção.

\section{Comissionismo: entre imparcialidade e proximidade-perspectiva}

A ausência de autorização expressa daqueles que são presumidamente representados pelas comissões da verdade amplia o desafio representativo ao deslocá-lo da zona axiomática e confortável do voto. As figuras de legitimidade reivindicadas pelas e para as comissões da verdade não se restringem ao acordo sobre o efeito "profilático" das políticas de verdade e memória. Os regimes de validação das comissões como corpos representativos também foram atravessados por profundas diferenças. Elas têm sobretudo a ver com a definição dos critérios de escolha de comissionários, atores-chave que decidem sobre as metodologias de trabalho das comissões, selecionam, conduzem e publicizam (ou não) testemunhos, e produzem relatório final com narrativas de "verdade".

Depois de tratar de três importantes convergências entre comissões, na seção anterior, esta seção se dedica a investigar dois eixos de legitimidade em disputa entre comissionários - com diferentes níveis de articulação e explicitação do dissenso, mas sobretudo concentrada no conflito entre a Comissão Rubens Paiva e a Comissão Nacional da Verdade. Um dos princípios em disputa se aproxima do princípio de imparcialidade ativa, conforme uso de Rosanvallón, e o outro converge com a expectativa de proximidade, também apresentada por Rosanvallon, e perspectiva, tal como mobilizada por Iris Young. Embora Young elabore seu conceito a partir da observação de dinâmicas parlamentares - da ordem representativa tradicional, portanto -, sua categoria nos serve, com as devidas modulações, para refletir sobre recursos de legitimação do comissionismo.

Os dois eixos em questão ganharam forma política nas decisões sobre incluir ou excluir pessoas afetadas pela ditadura nos quadros de comissionários. Na ausência do voto como mecanismo de legitimação, essa definição comporta diferentes entendimentos sobre o processo representativo, não necessariamente concorrentes, mas em forte tensão com o princípio de diferenças complementares cogitado por Rosanvallón (2009). O primeiro entendimento, baseado num ideal de imparcialidade-engajada e em linha com parâmetros internacionais de comissões da verdade, orientou os parâmetros formais de organização da CNV e de outras comissões estaduais que emularam o seu exemplo. Em contraste, o outro princípio de seleção de comissionários rejeita o princípio de imparcialidade e deriva a autoridade moral de comissionários da sua condição de afetados pela ditadura. Neste caso, o engajamento é mais contundente: tem lastro em histórias de perseguição e vitimação pessoal. O comissionismo incluiu diferentes combinações e modulações locais desses dois princípios.

O primeiro dos princípios - de imparcialidade ativa - ganhou forma exemplar na CNV, cuja lei de criação (no. 12.528, de 18 de novembro de 2011) define que seus membros sejam pessoas de "reconhecida idoneidade e conduta ética, identificados com a defesa da democracia e da institucionalidade constitucional, bem como com o respeito aos direitos humanos". No mesmo artigo da lei, define-se ainda o interdito à participação daqueles que "não tenham condições de atuar com imparcialidade no exercício das competências da Comissão". Na prática, além da exclusão de militares e figuras associadas ao exercício ou aos valores políticos da ditadura, a interpretação desta cláusula significou a composição de um corpo de comissionários não diretamente afetados pelo regime, isto é, pessoas que, reputadas pelo compromisso com a democracia e os direitos humanos, não foram presas, torturadas, constrangidas a esconder-se ou a exilar-se em decorrência de ações da ditadura. A premissa de fundo era de que 
${ }^{25}$ Por representados entenda-se a população de afetados pela violência da ditadura ou, numa concepção ampliada, a população como um todo, a quem interessa, em princípio, o conhecimento sobre o passado.

${ }^{26}$ Discurso de Dilma Rousseff em 16 de maio de 2012, adaptado. Fonte: www.biblioteca.presidencia.go v.br. a afetação direta de comissionários pelo regime poderia comprometer a isenção de seus trabalhos.

Neste caso, o perfil imputado a comissionários tem afinidade com a atitude de "imparcialidade ativa", descrita por Rosanvallón como uma das figuras de legitimidade da democracia contemporânea, calcada na expectativa de atores avessos a pré-julgamentos, mas situados em um mundo de paixões, conflitos e, portanto, parcialidades. Distante da introspecção racional dos homens na condição de ignorância imaginada por John Rawls (RAWLS 1997), os comissionários, lidos na chave da imparcialidade ativa, definem sua ação "em meio a um cara a cara corrosivo" (ROSANVALLÓN 2009, p.161). A imparcialidade em questão não é esvaziada de lado, portanto, mas tampouco está encarcerada em "posições fechadas" (ROSANVALLÓN 2009, p.162). Na versão encarnada na $\mathrm{CNV}$, a premissa é de que comissionários implicados pessoalmente com os objetos de investigação potencialmente extrapolam o compromisso estrito com a ação reparadora. A definição de biografias alheias às marcas diretas da ditadura, embora de algum modo identificadas com valores democráticos, é motivada pelo objetivo de "independência", que se supõe requisito de imparcialidade. Na delicada economia da representação identificada por Rosanvallón e operada pela CNV, a distância estabelecida entre ela [CNV] e os represen$\operatorname{tados}^{25}$, pela via da autonomia ou da imparcialidade, é compensada pelo compromisso de seus comissionários com os valores da democracia e dos direitos humanos.

O princípio de um apaixonamento moderado compôs a cena pública construída pelo governo em torno da CNV, pontuada pelo choro da então presidente Dilma Rousseff (2011-2016), ela própria vítima da ditadura, nas cerimônias de posse e encerramento da comissão. No discurso de Rousseff, ela esclarece não ter sido "movida por critérios pessoais ou por avaliações subjetivas" e descarta as possibilidades de "revanchismo" e "acerto de contas". "Escolhi um grupo de cidadãos e cidadãs de reconhecida competência, sensatos e ponderados, preocupados com a justiça e o equilíbrio" 26 , afirma. Sua escolha não mobiliza argumentos de proximidade, mas de sensibilidade para as causas dos direitos humanos, incluindo as ideias relacionadas com democracia e "verdade".

A ênfase na ação moderada, sem laços sociais ou biográficos entre os diferentes atores do processo representativo (isto é, comissionários e vítimas), aproxima a CNV dos parâmetros de comissões da verdade no mundo. Em casos de sociedades radicalmente divididas pelo conflito político, sem partes passíveis de "autonomia de juízo" e empatia universalista, reféns de "posições fechadas", a busca de moderação engajada toma forma em duas estratégias. Uma delas opera com um princípio de equilíbrio de antagonismos: comissões de composição diversificada devem diluir ou cancelar disposições muito parciais. A segunda estratégia é a de constituir corpos híbridos, misturando atores nacionais e estrangeiros (como nos casos do Haiti, da Guatemala, de Serra Leoa e Libéria), ou mesmo constituir comissões com quadros estritamente internacionais - como em El Salvador (HAYNER 2011). Neste caso, a expectativa é que a expertise em advocacia internacional de direitos humanos e a imunidade em relação a redes de poder, afeto e fidelidade locais se combinem em vista da "imparcialidade ativa", na acepção referida por Rosanvállon.

Em aberto enfrentamento com tal paradigma de imparcialidade, Adriano Diogo, então deputado estadual pelo estado de São Paulo e presidente da Comissão Rubens Paiva, refere-se à CNV como uma espécie de anti-modelo de ação: "enquanto na Nacional [CNV] não podia ter família envolvida, militante, aqui tinha tudo isso". Investidos de uma relação apenas intelectual com a ditadura, faltaria aos comissionários da CNV "vivência" (HOLLANDA 2019a, p.22) e "naturalidade" para lidar com o assunto (HOLLANDA 2019a, p.15). 
27 Por se tratar de uma comissão legislativa, a composição de comissionários da Comissão Rubens Paiva obedeceu a critérios formais de comissões parlamentares, com representação partidária variada. Sua construção simbólica, contudo, se fez em torno da figura de assessores que foram - sabida e notoriamente - vítimas da ditadura.
Em uma linguagem de confronto com a CNV, a CRP mobilizou outra figura-chave de legitimidade democrática - e representativa - contemporânea segundo Rosanvallón: a proximidade (ROSANVALLÓN 2009). Ela teria se colocado em evidência, desde fins dos anos 1990, como uma "nova figura do bem político" refratária a exercícios automáticos da norma que são, via de regra, insensíveis às circunstâncias particulares da vida dos cidadãos. Atento aos contextos francês e estadunidense, o autor francês identifica uma expectativa social difundida de escuta. Mais do que o benefício próprio no resultado da interação com setores públicos, os cidadãos esperariam - e valorizariam sobretudo - a consideração por sua situação particular, o afrouxamento dos rigores universais para acomodar circunstâncias não universais. $\mathrm{O}$ desafio posto era $\mathrm{o}$ de recorporificar o político e reagir aos sentimentos de "abandono", "esquecimento, indiferença e desprezo” (ROSANVALLÓN 2009, p.274).

Autor da proposta de criação da CRP como comissão parlamentar, Adriano Diogo (PT) foi ele próprio preso e torturado por agentes da ditadura e, desde então, vinculou sua figura pública, entre outras pautas, à denúncia da repressão política. Embora constituída conforme as exigências formais de comissões parlamentares, com representantes de diversos partidos políticos - que, na prática, "apenas iam lá dar sua assinatura" -, o deputado-comissionário referese à comissão paulista como uma "comissão de esquerda, uma comissão militante", de "familiares" (HOLLANDA 2019a, p.6). Para assegurar este perfil, nomeou assessores ${ }^{27}$ que se tornaram sua principal face pública: militantes historicamente envolvidos com a pauta dos crimes da ditadura, ex-presos políticos e torturados por agentes da ditadura.

Sua premissa de partida invertia, portanto, a da CNV: são justamente os afetados pelo regime militar que terão melhores condições de representar a "verdade" dos que partilharam o sofrimento com eles. Eles estão há décadas envolvidos na "luta contra o esquecimento". A CRP radicaliza o princípio de escuta contido em toda comissão de verdade ao localizar as vítimas não apenas nos lugares de testemunho, mas também na condução de trabalhos da comissão. Aqui está um importantíssimo aspecto de dissonância em relação ao desenho mais corrente de comissões da verdade no mundo.

No discurso do deputado comissionário da CRP, "toda vez que o Estado/ o governo/ a estrutura oficial entra na questão da ditadura, entra pela porta dos fundos, faz uma enorme confusão", ao invés de "entrar pelo lado da naturalidade, dos familiares das vítimas, dos atingidos, quer entrar pela superestrutura. Isso está errado" (HOLLANDA 2019a, p.16). Nesta perspectiva, técnica e conhecimento profissionais estão por definição aquém da experiência vivida, intransferível e incomunicável. Entre afetados e não afetados pelo regime haveria um abismo intransponível. O argumento da naturalidade é articulado, portanto, contra a expertise ou a técnica como condição suficiente da ação política: "a Comissão Nacional da Verdade veio organizada com pessoas e instituições que não tinham familiaridade com os fatos que elas estavam trabalhando. Isso gerou muitas distorções". Haveria ali, nos postos de comissionários, "grandes advogados, juristas... Pessoas maravilhosas, mas que não entendem nada de ditadura", com ressalva para Rosa Cardoso, que se envolveu, ainda durante a ditadura, na defesa de inúmeros presos políticos (HOLLANDA 2019a, p.12).

A comissão paulista fixa no centro de sua criação identitária a necessidade de representantes e representados compartilharem um ponto de observação comum da realidade - ou, no vocabulário de Iris Young, uma certa perspectiva social (YOUNG 2001). A CRP acolhe a premissa de que experiências aproximadas de vida fundam sensibilidades comuns que devem ser representadas - 
28 As aspas são para explicitar que se trata de uma categoria nativa, mobilizada por diferentes comissionários que concederam entrevista para os autores deste artigo. como condição de coerência ou ausência de "distorções" do processo representativo.

A aproximação com Young exige, contudo, uma importante modulação: na $\mathrm{CRP}$, o sentido de perspectiva não está referido às categorias mais usuais de pertencimento social, como classe, raça e gênero. A afinidade entre representantes e representados em questão está fixada na experiência comum e passada da violência - que aproxima as pessoas não pelo nascimento, mas pela escolha política de resistir à ditadura. São os mecanismos de memória social e política que forjam um sentido comum de identidade. A "naturalidade" referida pelo comissionário paulista - isto é, a contiguidade entre as partes do processo representativo ("vítimas" e comissionários) - é justamente objeto de construção da CRP. A noção abrangente de "voz das vítimas" - que aproximamos da ideia de Young sobre perspectiva - abarca diferentes grupos sociais, como estudantes, operários, indígenas e outros segmentos perseguidos pelo regime. Nesta acepção, a condição de "vítima"28, a despeito das distintas origens sociais dos atores, define sua "posicionalidade" [positionality] (YOUNG 2001), e dela não deriva uma ou outra narrativa necessária sobre a ditadura. Nas palavras do comissionário paulista: "não sei a que conclusão vão chegar, mas são as pessoas habilitadas para fazer este trabalho". Ainda em linha com Young, não há enunciados de "verdade" - ou conteúdos de representação - que possam ser conhecidos a priori como resultado das sensibilidades partilhadas.

No processo de multiplicação das comissões pelos estados e municípios do país, a autoridade moral emprestada à figura do comissionário afetado - envolvido, portanto, com a causa representada - foi uma característica marcante. No comentário de um comissionário do Rio de Janeiro sobre a presença de "familiares e ex-presos políticos", o sentido de naturalidade vem novamente à tona: "essa é a vida deles, né? São décadas com essa pauta muito presente. Eles tinham que estar aqui”. Em Santa Catarina, na mesma linha, o comissionário entrevistado comenta sobre a presença, na Comissão, de uma colega que foi presa e torturada durante o regime autoritário: "não consigo imaginar alguém que possa questionar a presença dela. Ela é a memória viva da ditadura no estado [de Santa Catarina]".

Na Tabela 1, a população de comissionados é apresentada conforme sua condição afetada ou não pela ditadura - tendo-se em vista o sentido mais estrito de afetação que vimos adotando ao longo deste artigo, sem referência a aspectos mais gerais da afetação que atingiram a população como um todo, como a restrição de liberdade política. Quando, no quadro dos comissionários, pelo menos um deles foi diretamente afetado pela ditadura, a comissão foi classificada como "afetada". Caso contrário, ela recebeu a denominação "não afetada". Por meio da consulta direta a comissionários e também a fontes abertas de pesquisa - como jornais, blogs e redes sociais - mapeamos o perfil de afetação ou não de 310 comissionários vinculados a 45 diferentes comissões estatais que compõem nosso universo de investigação.

Tabela 1 - Afetação das comissões

\begin{tabular}{lccc}
\hline Comissões & Afetadas & Não Afetadas & Sem Informação \\
\hline CNV & 0 & 1 & 0 \\
Estatuais & 9 & 7 & 0 \\
Municipais & 15 & 11 & 3 \\
Total & 24 & 19 & 3 \\
\hline
\end{tabular}

Fonte: elaboração própria. 
Embora o número absoluto de comissionários afetados seja menor do que o de não afetados (255 não afetados versus 55 afetados no total), o predomínio de comissões afetadas assinala maior acolhimento do princípio de proximidade do que da imparcialidade ativa. O que fica claro na análise dos dados (Tabela 2) é que a chance de uma comissão "afetada" contribuir com uma "afetada" e de uma "não afetada" contribuir com uma "afetada" é sempre maior do que a de uma "afetada" contribuir com uma "não afetada" e uma "não afetada" contribuir com uma "não afetada". Isto significa que ser "afetada" implica um fluxo de ajuda às demais comissões ("afetadas" e "não afetadas"), o que é endossado pelo grafo (Figura 3), sendo resultado, em parte, da centralidade das comissões dos estados de São Paulo e Rio de Janeiro, ambas "afetadas". As entrevistas com comissionários endossam esse diagnóstico. Nelas, é recorrente a referência à afetação de comissionários como justificativa de atuação nas e das comissões, em linha com o princípio da proximidade. A afetação é, portanto, um aglutinador de contribuições e as comissões afetadas concentram os principais nós nas relações da rede (Figura 3), à exceção da CNV, que acumula o maior número de ligações com outras comissões por motivos que vão além das relações de afetação que nos importa analisar. Com uma vasta equipe de assessores e pesquisadores, orçamento e estrutura de funcionamento muitíssimo superiores aos de todas as demais comissões, seu efeito de atração rendeu frutos. A transmissão de ferramentas metodológicas foi, possivelmente, o maior deles.

Nesta seção, identificamos, na complexa teia de comissões da verdade no Brasil, princípios dissonantes - ou mesmo conflitantes - na definição dos operadores da representação legítima. Face à ausência ou aos frágeis instrumentos de autorização social de comissionários, sua pretensão de legitimidade oscila com o tipo de laços que evoca com a causa dos direitos humanos e com as "vítimas" que representam. Na CNV, a expectativa de legitimidade reside na boa estatura moral da causa - os direitos humanos - e numa medida de boa distância dos comissionários em relação aos objetos e objetivos da comissão. Em contraste, a CRP toma a crítica da CNV por princípio e compreende a afetação do comissionado como critério de legitimidade, articulando um sentido de contiguidade entre comissionários e depoentes, ou entre representantes e representados. Embora no choque entre CRP e CNV os dois princípios - de imparcialidade ativa e proximidade - configurem uma polaridade estrita, não chegam a constituir formas puras, categorias isoladas ou mutuamente exclusivas. Na composição de seus quadros, por exemplo, a CNV se aproximou do polo da proximidade com o seu Grupo de Trabalho dos Trabalhadores, ou GT 13, composto apenas por figuras sabidamente afetadas pela violência da ditadura. Quanto à CRP, cercou-se de um corpo técnico jovem e qualificado, sem afetação direta pela ditadura e afinado com o perfil do ativismo em direitos humanos da CNV.

O contraste ou a ambiguidade entre os dois princípios pode ser explícito e articulado, ou apenas discreto e entrevisto. As críticas abertas da CRP em relação à $\mathrm{CNV}$ encarnam a versão patente da dissonância. Já a composição híbrida de comissões, combinando comissionários afetados e não afetados pela ditadura, constitui a versão discreta do contraste. Houve comissões em que um

Tabela 2 - Contribuição entre comissões

\begin{tabular}{lcc}
\hline Comissões & Afetada (Recebe) & Não Afetada (Recebe) \\
\hline Afetada (Contribui) & 40 & 16 \\
Não Afetada (Contribui) & 36 & 6 \\
\hline
\end{tabular}

Fonte: Elaboração própria. 
único comissionário-vítima foi saudado e aludido como reserva moral do grupo (a exemplo da Comissão Estadual da Verdade Paulo Stuart Wright, Santa Catarina); e houve outras, com maior densidade de comissionários-vítimas, que não produziram uma fala pública sobre sua composição e simplesmente operaram o princípio da proximidade, sem articular um discurso sobre ele (a exemplo da Comissão da Verdade em Minas Gerais). Os laços cruzados de solidariedade entre atores com diferentes perfis institucionais, biográficos e geracionais contribuíram para normalizar, nos espaços das comissões, a legitimidade da ação política de pessoas diretamente afetadas pela ditadura, cujos sofrimentos individual e/ou familiar foram articulados como metáfora do sofrimento social de uma geração de resistentes à ditadura.

Conforme cogitado por Rosanvallón, embora imparcialidade ativa e proximidade correspondam a diferentes expectativas sobre a arena pública e a democracia, podem ser combinadas e experimentadas em simultâneo. No Brasil, o comissionismo experimentou fortes tensões e também complementaridade entre suas partes.

\section{Considerações finais}

\footnotetext{
${ }^{29}$ Este foi o caso, por exemplo, do próprio Adriano Diogo. Quando o mandato da Comissão Rubens Paiva se encerrou juntamente com seu mandato como deputado estadual e ele não conseguiu ser reeleito, passou a constituir, na qualidade de "membro da sociedade civil, os quadros da Comissão da Memória e Verdade da Prefeitura de São Paulo.
}

As comissões de verdade no Brasil aproximaram atores do governo e de segmentos organizados da sociedade em articulações estreitas atravessadas por convergências e tensões. Valeram-se de iniciativas, mecanismos e acúmulos políticos dos dois conjuntos de atores, dentro e fora das fronteiras formais do Estado. Foram também negativamente afetadas por entraves formais, desmobilização e esvaziamento político de seus operadores estatais e sociais. Inaugurado em dezembro de 2011, o comissionismo viveu as eleições de 2014 e a renovação de mandatos políticos nos estados, quando as duas dimensões em questão - Estado e sociedade - se fizeram ainda mais imbricadas, com a circulação de comissionários entre movimentos sociais e cargos eletivos ${ }^{29}$.

Embora os membros das comissões vinculadas a instâncias de Estado não tenham sido eleitos por voto, suas dinâmicas de trabalho estiveram fortemente associadas ao mundo eleitoral. As comissões incorporaram atores autorizados pelo voto, de maneira direta (caso de deputados e vereadores) ou indireta (caso de secretários e funcionários de governo em geral) e, no caso específico de comissões legislativas, seus calendários estiveram estritamente condicionados pelos tempos de legislatura. A aproximação das comissões com o domínio eleitoral também compôs seu complexo e disputado repertório de demandas representativas. A afirmação do comissionário paulista de que seu trabalho na CRP é parte de sua função de "representante do povo" é elucidativa da "legitimidade derivada" observada por Rosanvallon nos fóruns que emergiram na cena democrática em fins dos anos 1990.

Mas a reivindicação de validação eleitoral indireta foi apenas um recurso marginal de atores ligados ao comissionismo. Como se viu ao longo do artigo, seus repertórios de legitimidade estiveram sobretudo pautados na premissa de uma simbiose de sentidos entre democracia e direitos humanos, o que aproxima o fenômeno de alguns dos parâmetros gerais de comissões da verdade no mundo. Outro laço importante de afinidade entre as experiências brasileira e internacional se estabeleceu em torno do princípio de imparcialidade ativa. No Brasil, ele foi tipicamente encarnado pela CNV e associado a dois ideais básicos da militância em direitos humanos: moderação e engajamento. Não há dúvidas da afinidade da experiência de parte do comissionismo com os princípios mais gerais que orientam e orientaram as comissões da verdade no mundo.

Porém, a polissemia contida na categoria ampla dos direitos humanos não nos permite descrever o fenômeno brasileiro apenas a partir do prisma das 
convergências. Ele é melhor compreendido a partir das dissonâncias em relação ao modelo internacional das comissões da verdade. A primeira seção do artigo se dedicou a caracterizar uma das dimensões dessa discrepância: a condição profundamente heterogênea do comissionismo, em contraste com a organização sempre nacional de comissões da verdade no mundo. Sem negligenciar o protagonismo da CNV na cena nacional das comissões da verdade, buscamos mostrar como o fenômeno de proliferação de tais estruturas ultrapassou suas fronteiras e diretrizes de ação, constituindo uma rede complexa, dispersa em diferentes tempos e lugares institucionais, com estruturas investidas de autonomia de mandato, iniciadas por diversos partidos políticos e organizadas em torno de eixos locais de colaboração.

Depois de, na segunda seção, investigarmos elementos de uma subjetividade comum a comissionários, retornamos, na terceira seção, à caracterização de outro aspecto da dissonância entre o fenômeno brasileiro e a praxe internacional de comissões da verdade: a ausência, no comissionismo, de uma distinção necessária de perfis entre testemunhos e comissionários. É normalmente na figura do comissionário que recaem as expectativas de ação moderada (ou equilibrada) das comissões - entre aqueles que assim a concebem. Sua nãoafetação pela violência sob investigação é o que garantiria a independência necessária para reunir o mosaico de sofrimentos particulares e familiares em narrativa coerente, abrangente e imparcial. O contraponto reivindicado pela CRP e operado tacitamente pela maior parte das comissões - isto é, por todas aquelas que definimos como afetadas - se organiza em torno das ideias de "vivência" e "pessoalidade" e também da habilitação de "vítimas" como operadoras de comissões.

É precisamente aqui - entre outros âmbitos - que as comissões subnacionais da verdade inovaram em relação à $\mathrm{CNV}$ e às comissões da verdade em geral. A inclusão de vítimas nos corpos de comissionários foi um elemento-chave embora não exclusivo - de seu impulso expansivo e de sua dissonância em relação ao campo da justiça de transição no mundo. A feição predominante do comissionismo se concentrou no eixo proximidade-perspectiva - em linguagem nativa, na "vocação militante" -, imune às recomendações de desapaixonamento e baseada na assunção explícita do ponto de vista das vítimas ou na "verdade das vítimas".

Cristina Buarque de Hollanda (cristinabuarque@ iesp.uerj.br) é bacharel em Ciências Sociais pela Universidade Federal do Rio de Janeiro (2000), mestre (2002) e doutora (2007) em Ciência Política pelo Instituto Universitário de Pesquisas do Rio de Janeiro (IUPERJ).

Vinícius Pinheiro Israel (visrael@gmail.com) possui doutorado em Sociologia pelo Programa de Pós-Graduação em Sociologia (PPGS) do Instituto de Estudos Sociais e Políticos (IESP) da Universidade do Estado do Rio de Janeiro (UERJ, Brasil) e doutorado em Estatística pelo Programa de Pós-Graduação em Estatística da Universidade Federal do Rio de Janeiro (UFRJ, Brasil), mestrado pelo Programa de Pós-Graduação em Informática (PPGI) da UFRJ e bacharelado em Matemática pela UFRJ e em Ciências Sociais pela UERJ.

\section{Referências bibliográficas}

Abrão \& Torelli, (2011). As dimensões da Justiça de Transição no Brasil, a eficácia da Lei de Anistia e as alternativas para a verdade e a justiça. In L. A. Payne; P. Abrão \& M. D. Torelly (orgs). A Anistia da era da responsabilização: o Brasil em perspectiva internacional e comparada. Oxford: University of Oxford, pp.212-249.

Azevedo, Desirée, 2018. Ausências Incorporadas. Etnografia entre familiares de mortos e desaparecidos políticos no Brasil. São Paulo: Editora Unesp.

Agresti, Alan, 2013. Categorical Data Analysis. Nova Jersey: John Wiley \& Sons.

Avritzer, Leonardo, 2007. Sociedade civil, instituições participativas e representação: da autorização à legitimidade da ação. Dados, 50(3), pp.43-464. DOI: 10.1590/S0011-52582007000300001

Avritzer, Leonardo, 2008. Instituições participativas e desenho institucional: algumas considerações sobre a variação da participação no Brasil democrático. Opinião Pública, 14(1), pp.43-64. DOI: 10.1590/S0104-62762008000100002 
Boraine, Alex, 2000. A country unmasked. Oxford: Oxford University Press.

Hayner, Priscila, 2011. Unspeakable Truths: Transitional Justice and the Challenge of Truth Commissions. Nova York \& Londres: Routledge.

Hungtinton, Samuel P., 1994. A terceira onda: a democratização no final do século XX. São Paulo, Ática.

Kritz, Neil, 2004, Transitional justice: how emerging democracies reckon with former regimes. Washington, D.C., United States Institutes of Peace Press, 2004

Lavalle, Adrian Gurza, 2006a. Representação política e organizações civis. Novas instâncias de mediação e os desafios da legitimidade. Revista Brasileira de Ciências Sociais, 21(60), pp. 43-66. DOI: 10.1590/S0102-69092006000100003

Lavalle, Adrian Gurza, 2006b. Democracia, pluralização da representação política e sociedade civil. Lua Nova, 67, pp.49-103. DOI: $10.1590 / \mathrm{S} 0102-64452006000200004$

Lavalle, Adrian Gurza \& Vera, Ernesto Isunza, 2011. A Trama da crítica democrática: da participação à representação e à accountability. Lua Nova, 84, pp.353-364. DOI: 10.1590/S0102-64452011000300005

Lavalle, Adrian Gurza et al., 2019. Movimentos sociais e institucionalização: políticas sociais, raça e gênero no Brasil pós-transição. Rio de Janeiro: EdUERJ.

Lüchmann, Lígia, 2011. Associações, participação e representação: combinações e tensões. Lua Nova, 84, pp.353-364. DOI: 10.1590/S0102-64452011000300006

Mezarobba, Glenda. Um acerto de contas com o futuro - a anistia e suas consequências: um estudo do caso brasileiro. São Paulo: Humanitas/Fapesp, 2006.

Miguel, Luiz Felipe, 2005. Impasses da Accountability: dilemas e alternativas da representação política. Revista Sociologia e Política, 25, pp.25-38. DOI: 10.1590/S0104-44782005000200004

Miguel, Luiz Felipe, 2011. Representação democrática: autonomia e interesse ou identidade e advocacy. Lua Nova, 84, pp.353-364. DOI: 10.1590/S0102-64452011000300003

Pogrebinschi, Thamy \& Santos, Fabiano, 2011. Participação como Representação: o Impacto das Conferências Nacionais de Políticas Públicas no Congresso Nacional. Dados, 54(3), pp.259-305. DOI: 10.1590/S0011-52582011000300002

Rawls, John, 1997. Uma teoria da justiça. São Paulo: Martins Fontes.

Rosanvallon, Pierre, 2009. La legitimidad democrática: imparcialidad, reflexividad, proximidad. Buenos Aires: Manantial.

Saward, Michael, 2010. The Representative Claim. Oxford: Oxford Univeristy Press.

Sikkink, Kathryn, 1995. Justice Cascade. How Human Rights Prosecutions are changing World Politics. Nova York, Londres: W.W Norton \& Company.

Simoni, Maria Yokoya, 2016. Justiça em transição no Brasil. Anistia política e reparação dos militantes da Guerrilha do Araguaia. Jundiaí: Paco Editorial.

Skocpol, T., 1992. Protecting soldiers and mothers: the political origins of social policy in the United States. Cambridge: Belknap Press/Harvard University Press.

Stan, Lavinia \& Nadelsky, Nadya (orgs), 2014. Transitional Justice Encyclopedia. Cambridge: Cambridge University Press. Tutu, Desmond, 1999. No future without forgiveness. Londres: Rider.

Wilson, Richard A., 2001. The Politics of Truth and Reconciliation in South Africa. Cambridge: Cambridge University Press.

Young, Iris, 2001. Inclusion and Democracy. Oxford: Oxford University Press.

\section{Outras fontes}

Hollanda, Cristina Buarque de, (2019a). Entrevista com Adriano Diogo (CEV Rubens Paiva, SP-SP). figshare. Online resource. Disponível em: https://doi.org/10.6084/m9.figshare.8230727.v2 Acesso em 30 de junho de 2019.

Hollanda, Cristina Buarque de, (2019b). Entrevista com Dorival Santos (Comissão Estadual da Verdade do Amapá). figshare. Online resource. Disponível em: https://doi.org/10.6084/m9.figshare.8307077.v1 Acesso em 30 de junho de 2019.

Hollanda, Cristina Buarque de, (2019c). Entrevista com Manoel Severino Moraes (CEMVDHC). figshare. Online resource. Disponível em: https://doi.org/10.6084/m9.figshare.8243123.v1 Acesso em 30 de junho de 2019.

Hollanda, Cristina Buarque de, (2019d). Entrevista com Norton Nohama (Comissão da Verdade do Paraná Teresa Urban). figshare. Online resource. Disponível em: https://doi.org/10.6084/m9.figshare.8378963.v1 Acesso em 30 de junho de 2019.

Hollanda, Cristina Buarque de, (2019e). Entrevista com Paulo Nunes (Comissão da Verdade e da Preservação da Memória da Paraíba. figshare. Online resource. Disponível em: https://doi.org/10.6084/m9.figshare.8378969.v1 Acesso em 30 de junho de 2019.

Sikkink, Kathryn \& Marchesi, Bridget, 2015. Nothing but the Truth: Brazil's Truth Commission Looks Back. Foreign Affairs, 26, fev. Disponível em: http://www.foreignaffairs.com/articles/143180/kathryn-sikkink-and-bridget-marchesi/nothingbut-the-truth?cid=nlc-foreign_affairs_this_week-030515-nothing_but_the_truth_5030515\&sp_mid=48163663\&sp_rid=aWV2YUB1ZmwuZWR1S0. Acesso em: 10 de out. de 2019. 
Panorama of Truth Commissions in Brazil: a reflection on new understandings of democratic legitimity and representation

ABSCTRACT Introduction: The National Truth Commission (NTC) in Brazil, established in May 2012, investigated human rights violations perpetrated by the civil-military dictatorship (1964-1985) almost thirty tears after the new democracy in the country. It triggered the subsequent creation of a large number of non-national truth commissions, a phenomenon we name commissionism. This article describes it and investigates the large body of representative claims articulated by truth commissions. Materials and Methods: The analysis is based on data collected by the authors, including the final reports of truth commissions, research on social media, local and national press, and interviews with commissioners. Results: We sustain that the fundamental shared trait of the representative claims deployed by the non-national truth commissions in Brazil involves conceptualizing victims as legitimate representatives, who are qualified by the moral authority of their experience, in contrast with other national truth commissions. Discussion: Truth commissions are non-elected bodies that lack traditional accountability mechanisms at their inception. Their actors have agreed and disagreed over their legitimate foundations. On the one side, they agree on the moral objective of Human Rights and on the assumption that they are achieved by exposing the "truth" about the violent past. On the other side, there is substantial disagreement about the driving values behind the commissions, which can to some extent be described by the notions of active impartiality and proximity, such as articulated by Pierre Rosanvalón, and perspective, such as articulated by Iris Young.

KEYWORDS: truth commissions; democracy; human rights; legitimity; representation.

This is an Open Access article distributed under the terms of the Creative Commons Attribution Non-Commercial License which permits unrestricted non-commercial use, distribution, and reproduction in any medium provided the original work is properly cited. 


\section{Apêndice 1}

Tabela 1A - Comissões pesquisadas com as siglas utilizadas nos gráficos do trabalho

\begin{tabular}{|c|c|c|c|c|c|}
\hline SIGLA* & NOME & SIGLA & NOME & SIGLA & NOME \\
\hline CNV & $\begin{array}{l}\text { Comissão Nacional } \\
\text { da Verdade }\end{array}$ & CEV-SE & $\begin{array}{l}\text { Comissão Estadual da } \\
\text { Verdade Paulo Bar- } \\
\text { bosa de Araújo } \\
\text { [Sergipe] }\end{array}$ & $\begin{array}{l}\text { CMV- } \\
\text { S.B.Campo }\end{array}$ & $\begin{array}{l}\text { Comissão Municipal } \\
\text { da Verdade de São } \\
\text { Bernardo do Campo }\end{array}$ \\
\hline CEV-AL & $\begin{array}{l}\text { Comissão Estadual } \\
\text { da Memória e } \\
\text { Verdade Jayme } \\
\text { Miranda [Alagoas] }\end{array}$ & CEVAL-SP & $\begin{array}{l}\text { Comissão da Verda- } \\
\text { de do Estado de São } \\
\text { Paulo (Legislativa) - } \\
\text { Rubens Paiva (CRP) }\end{array}$ & CMV-Maua & $\begin{array}{l}\text { Comissão Municipal } \\
\text { da Verdade de Mauá }\end{array}$ \\
\hline CEV-AP & $\begin{array}{l}\text { Comissão Estadual } \\
\text { da Verdade do } \\
\text { Amapá "Chaguinha" }\end{array}$ & CMV-Araras & $\begin{array}{l}\text { Comissão da Verdade } \\
\text { da Câmara Municipal } \\
\text { de Araras }\end{array}$ & $\begin{array}{l}\text { CMV- } \\
\text { S.Gonçalo }\end{array}$ & $\begin{array}{l}\text { Comissão Municipal } \\
\text { da Verdade de São } \\
\text { Gonçalo }\end{array}$ \\
\hline CEVAL-BA & $\begin{array}{l}\text { Comissão Especial da } \\
\text { Verdade da Assem- } \\
\text { bleia Legislativa da } \\
\text { Bahia }\end{array}$ & CMV-Bauru & $\begin{array}{l}\text { Comissão Municipal } \\
\text { da Verdade de Bauru } \\
\text { Irmãos Petit }\end{array}$ & $\begin{array}{l}\text { CMV- } \\
\text { S.J.Campos }\end{array}$ & $\begin{array}{l}\text { Comissão Municipal } \\
\text { da Verdade de São } \\
\text { José dos Campos }\end{array}$ \\
\hline CEV-BA & $\begin{array}{l}\text { Comissão Estadual } \\
\text { da Verdade da Bahia }\end{array}$ & CMV-SP & $\begin{array}{l}\text { Comissão da Memória } \\
\text { e Verdade da Pre- } \\
\text { feitura do Município } \\
\text { de São Paulo }\end{array}$ & $\begin{array}{l}\text { CMV- } \\
\text { Sorocaba }\end{array}$ & $\begin{array}{l}\text { Comissão Municipal } \\
\text { da Verdade [Sorocaba] }\end{array}$ \\
\hline CEVAL-ES & $\begin{array}{l}\text { Comissão Especial da } \\
\text { Verdade da Assem- } \\
\text { bleia Legislativa do } \\
\text { Espírito Santo }\end{array}$ & CMVCV-SP(1) & $\begin{array}{l}\text { Comissão Municipal } \\
\text { da Verdade Vladimir } \\
\text { Herzog [primeira } \\
\text { legislatura] }\end{array}$ & $\begin{array}{l}\text { CMV- } \\
\text { V.Redonda }\end{array}$ & $\begin{array}{l}\text { Comissão Municipal } \\
\text { da Verdade de Volta } \\
\text { Redonda }\end{array}$ \\
\hline CEV-ES & $\begin{array}{l}\text { Comissão Estadual da } \\
\text { Memória e Verdade } \\
\text { [Espírito Santo] }\end{array}$ & CMVCV-SP(2) & $\begin{array}{l}\text { Comissão Municipal } \\
\text { da Verdade Vladimir } \\
\text { Herzog [segunda legis- } \\
\text { latura] }\end{array}$ & $\begin{array}{l}\text { CMV- } \\
\text { Petropolis }\end{array}$ & $\begin{array}{l}\text { Comissão Municipal } \\
\text { da Verdade de } \\
\text { Petrópolis }\end{array}$ \\
\hline CEV-GO & $\begin{array}{l}\text { Comissão Estadual da } \\
\text { Memória Verdade e } \\
\text { Justiça [Goiás] }\end{array}$ & CMV-Cubatao & $\begin{array}{l}\text { Comissão Municipal } \\
\text { da Verdade de Cuba- } \\
\text { tão }\end{array}$ & $\begin{array}{l}\text { CMV- } \\
\text { S.J.Meriti }\end{array}$ & $\begin{array}{l}\text { Comissão Municipal } \\
\text { da Verdade de São } \\
\text { João de Meriti }\end{array}$ \\
\hline CEV-MG & $\begin{array}{l}\text { Comissão da Verdade } \\
\text { de Minas Gerais }\end{array}$ & CMV-D.Caxias & $\begin{array}{l}\text { Comissão da Verdade } \\
\text { de Duque de Caxias }\end{array}$ & $\begin{array}{l}\text { CMV- } \\
\text { V.Conquista }\end{array}$ & $\begin{array}{l}\text { Comissão Municipal } \\
\text { da Verdade de Vitória } \\
\text { da Conquista }\end{array}$ \\
\hline CEV-PA & $\begin{array}{l}\text { Comissão Estadual da } \\
\text { Verdade e Memória } \\
\text { [Pará] }\end{array}$ & CMV-Joinville & $\begin{array}{l}\text { Comissão Municipal } \\
\text { da Verdade de } \\
\text { Joinville }\end{array}$ & $\begin{array}{l}\text { CMV- } \\
\text { Florianopolis }\end{array}$ & $\begin{array}{l}\text { Comissão Municipal } \\
\text { da Verdade de } \\
\text { Florianópolis }\end{array}$ \\
\hline CEV-PB & $\begin{array}{l}\text { Comissão Estadual } \\
\text { da Verdade e Pre- } \\
\text { servação da Memória } \\
\text { do Estado da Paraíba }\end{array}$ & CMV-J.Fora & $\begin{array}{l}\text { Comissão Municipal } \\
\text { da Verdade de Juiz de } \\
\text { Fora }\end{array}$ & CMV-J.Pessoa & $\begin{array}{l}\text { Comissão Municipal } \\
\text { da Verdade de João } \\
\text { Pessoa }\end{array}$ \\
\hline CEV-PR & $\begin{array}{l}\text { Comissão Estadual } \\
\text { da Verdade do } \\
\text { Paraná - Teresa } \\
\text { Urban }\end{array}$ & CMV-Macae & $\begin{array}{l}\text { Comissão Municipal } \\
\text { da Verdade de Macaé }\end{array}$ & $\begin{array}{l}\text { CMV- } \\
\text { Diadema }\end{array}$ & $\begin{array}{l}\text { Comissão Municipal } \\
\text { da Verdade de } \\
\text { Diadema }\end{array}$ \\
\hline CEV-PE & $\begin{array}{l}\text { Comissão da Verda- } \\
\text { de e da Memória do } \\
\text { Estado da Paraíba - } \\
\text { Dom Helder Câmara }\end{array}$ & CMV-Niteroi & $\begin{array}{l}\text { Comissão Municipal } \\
\text { da Verdade de Niterói }\end{array}$ & CMV-R.Pires & $\begin{array}{l}\text { Comissão Municipal } \\
\text { da Verdade de } \\
\text { Ribeirão Pires }\end{array}$ \\
\hline
\end{tabular}




\begin{tabular}{|c|c|c|c|c|c|}
\hline SIGLA* & NOME & SIGLA & NOME & SIGLA & NOME \\
\hline CEV-RJ & $\begin{array}{l}\text { Comissão Estadual da } \\
\text { Verdade do Rio de Ja- } \\
\text { neiro }\end{array}$ & CMV-N.Friburgo & $\begin{array}{l}\text { Comissão Municipal } \\
\text { da Memória Verdade } \\
\text { e Justiça Chico Bravo } \\
\text { [Nova Friburgo] }\end{array}$ & \multirow[t]{3}{*}{ CMV-S.Andre } & \multirow[t]{3}{*}{$\begin{array}{l}\text { Comissão Municipal } \\
\text { da Verdade da Câmara } \\
\text { de Santo André }\end{array}$} \\
\hline CEV-RS & $\begin{array}{l}\text { Comissão Estadual } \\
\text { da Verdade [Rio } \\
\text { Grande do Sul] }\end{array}$ & CMV-Osasco & $\begin{array}{l}\text { Comissão Municipal } \\
\text { da Verdade de Osasco }\end{array}$ & & \\
\hline CEV-SC & $\begin{array}{l}\text { Comissão Estadual } \\
\text { da Verdade de Santa } \\
\text { Catarina - Paulo } \\
\text { Stuart Wright }\end{array}$ & CMV-Santos & $\begin{array}{l}\text { Comissão Municipal } \\
\text { da Verdade de Santos }\end{array}$ & & \\
\hline
\end{tabular}

Fonte: Elaboração própria.

* Observe-se que as siglas foram compostas por nós em vista da facilitação de manuseio da informação nos gráficos e no banco de dados, e não correspondem necessariamente às siglas usadas pelas próprias comissões. Utilizamos CEV para Comissão Estadual da Verdade, CEAL para Comissão Estadual da Verdade da Assembleia Legislativa, CMV para Comissão Municipal da Verdade e CMVCV para Comissão Municipal da Verdade da Câmara de Vereadores. Em negrito estão assinaladas as comissões que acessamos, entre outros meios, a partir da entrevista com pelo menos um dos comissionários. As células preenchidas em cinza sinalizam as comissões com ao menos um comissionário afetado pela ditadura, informação que não está disponível para as seguintes comissões: CEVAL-BA, CEVAL-ES, CMV-Santos, CMV-V.Conquista e CMV-S.Andre. 